\title{
The Oral Literature Researcher as a Foreign Expert
}

\section{Lee Haring}

\section{(2) OpenEdition}

\section{Journals}

Electronic version

URL: https://journals.openedition.org/clo/367

DOI: $10.4000 /$ clo.367

ISSN: 2266-1816

\section{Publisher}

INALCO

\section{Printed version}

Date of publication: 1 January 2008

Number of pages: $426-451$

ISBN: 978-2-85831-181-1

ISSN: 0396-891X

\section{Electronic reference}

Lee Haring, "The Oral Literature Researcher as a Foreign Expert", Cahiers de littérature orale [Online], 63-64 | 2008, Online since 04 January 2012, connection on 07 July 2021. URL: http:// journals.openedition.org/clo/367 ; DOl: https://doi.org/10.4000/clo.367

This text was automatically generated on 7 July 2021.

\section{(c) (†) 8)}

Cahiers de littérature orale est mis à disposition selon les termes de la Licence Creative Commons Attribution - Pas d'Utilisation Commerciale 4.0 International. 


\title{
The Oral Literature Researcher as a Foreign Expert
}

\author{
Lee Haring
}

\section{EDITOR'S NOTE}

Portions of this essay are drawn from lectures the author gave at Gauhati University, Assam (India), in September 2006.

1 When I was residing in Mauritius (Île Maurice) as a visiting researcher in folklore, my wise host, who had much experience in receiving scholars from abroad, observed to me how often, in his country, foreign experts came, diagnosed, say, an economic situation, and made excellent recommendations to government. Then, he said, the recommendations went nowhere. One never heard about them again, and nothing changed. His forewarning enabled me to try to understand what forces of resistance impede development, in a so-called developing country. Much is known, for instance, about people's adherence to traditional agricultural methods even after more "modern" methods have been shown them (Sen, 1999). In Mauritius, there has been no tradition of cultural study; culture has been the stepchild of many ministries, though its recent move from the Ministry of Sport to a new Ministry of Arts and Culture is some improvement. The most successful project of oral literature research I oversaw there was one I did not even initiate: it was the work of a local collector researching his own society (Auleear and Haring, 2006). More and more, however, the researcher in oral literature will be called on to play the role of a foreign expert, either in his or her own culture or in a non-Western one, and to engage local people in honoring their own traditions.

2 Nations uncover and study oral literature in order to give themselves an ideological history.

Le folklore est né à partir d'une réflexion des sociétés industrielles sur ellesmêmes; il est significatif à cet égard qu'il soit apparu d'abord au sein des sociétés les plus “ordonnées", celles qui avaient développé la technologie la plus 
rationnelle, et en conséquence qui s'étaient les plus éloignées de la nature : les pays scandinaves et anglo-saxons; en ce sens, le folklore se présente comme un retour aux sources non dépourvu d'un certain accent romantique.

(Poirier, 1968: 567)

3 That is why the study of oral literature differs so much from nation to nation: each one sets its own priorities, ensuring that the research "goes somewhere", has some larger effect. In India, studies of oral literature, political beliefs, and ideological values have always gone together. In England of the 1840s, when an economic depression was provoking Thomas Carlyle to castigate the dehumanization around him in Past and Present (1843), W. J. Thoms invented the word Folk-lore to point to an alternative; he called out to the literate middle class to pay attention to the "manners, [etc.]... of the olden time", which they were moving away from. That would be the time before machines caused working-class people to protest the changes around them. In Britain and Europe, the study of "Folk-lore", including oral literature, was "a romantic invention designed as part of the ideology created by the emerging bourgeoisie to solve its identity problem" (Holbek, 1978: 29). In Germany, a few years before Thoms, the brothers Grimm offered their solution to their nation's identity problem: they made the tales they collected and published into the very voice of the German Volk. The reverent attitude they inspired in their readers gave folktales a special, almost mythical status, not only in Germany (Zipes, 1994:, 5). With time, the "folk" were defined as backward. By the middle of the twentieth century, an ideologue who edited the scholarly Journal of American Folklore could define the folk simply as the opposite of the bourgeoisie:

an unsophisticated, homogeneous group living in a politically-bounded advanced culture but isolated from it by such factors as topography, geography, religion, dialect, economics, and race.

(Greenway, 1964: xii)

Now there is a new, problematized version of the "folk" for the researcher to engage: the community.

In its 2003 Convention for the Safeguarding of the Intangible Cultural Heritage, UNESCO declared:

[...] les processus de mondialisation et de transformation sociale, à côté des conditions qu'ils créent pour un dialogue renouvelé entre les communautés, font, tout comme les phénomènes d'intolérance, également peser de graves menaces de dégradation, de disparition et de destruction sur le patrimoine culturel immatériel, en particulier du fait du manque de moyens de sauvegarde de celui-ci...

The Convention awards an important role to "communities":

Les communautés sont des réseaux de personnes dont le sentiment d'identité ou de lien naît d'une relation historique partagée, ancrée dans la pratique et la transmission de, ou l'attachement à, leur patrimoine culturel immatériel... les communautés, en particulier les communautés autochtones, les groupes et, le cas échéant, les individus, jouent un rôle important dans la production, la sauvegarde, l'entretien et la recréation du patrimoine culturel immatériel, contribuant ainsi à l'enrichissement de la diversité culturelle et de la créativité humaine [...] (http://unesdoc.unesco.org/images/0013/001325/132540f.pdf, consulted August 6, 2008)

7 Is it the practice and transmission of lore, then, that qualifies people as "folk"? UNESCO makes much of this concept of community. Oral literature research can make a difference. 
8 Researchers in oral literature have known several sorts of community, most often the "imagined" one, in the now-classic sense defined by Benedict Anderson (1991), a community whose main existence is mental. A "folk" was imagined to be

a people who over centuries and millennia had developed their own language, their own myths... their own culture. A folk was a distinct organized entity that existed in time as well as in place, and that thus could not be defined except in reference to its beginnings, its past, its history, the lines of transformation that connect present to past...

(Robert J. Smith, qtd in Abrahams, 1993: 10)

The imagining of this community, by those who don't belong to it, can be retroactively traced through the generations of scholars after Thoms. Here is George Lyman Kittredge on the ballad:

It appears that there is no lack of characteristic traits... which justify the conjecture that the history of balladry, if we could follow it back in a straight line without interruptions would lead us to a very simple condition of society, to the singing and dancing throng, to a period of communal composition.

(Sargent and Kittredge, 1904: xxii; Pound, 1921: 37)

9 A century later, the imaginary singing and dancing throng was a joke among folklore students in the United States. Kittredge's master in imagining was Francis Barton Gummere, for whom the folk were homogeneous and unlettered; their poetry was "public poetry, made in public, by the public", which he sometimes called a "horde" (Wilgus, 1959: 20, 13). The field anthropology of Franz Boas, Bronislaw Malinowski, Marcel Griaule, and their disciples sought to deflate this conception with direct observation, but it survives.

10 Within the community, UNESCO expects a particular group or individual to claim the right of representation.

Les groupes sont constitués de personnes issues d'une ou de plusieurs communautés qui partagent des caractéristiques telles que des savoir-faire, une expérience et des connaissances particulières et qui, à ce titre, jouent un rôle spécifique dans la pratique actuelle et future, la re-création et/ou la transmission de leur patrimoine culturel immatériel comme, par exemple, les gardiens, les praticiens ou les apprentis.

11 And many a researcher in oral literature has been blessed to find a gifted individual performer.

Les individus sont les personnes qui, issues d'une ou de plusieurs communautés, ont des savoir-faire, des connaissances, une expérience spécifique ou d'autres caractéristiques...

12 Such skilled and knowledgeable individuals, like the man I collaborated with in Mauritius, have been dedicated, conscious agents of cultural preservation, and acted as representatives of their community.

13 Representation is a foundational concept in aesthetics, semiotics and political theory, where it poses difficult problems. In oral literature studies, the politics of culture interpose several steps between performance and publication: interviewing, recording, transcription, and translation. One instant that has particularly prompted researchers to question themselves is the moment when a Western investigator writes down the words of a nonwestern oral piece, intending to publish them for a foreign audience (Baumgardt, 2008: 271-329). Immediately the issue of representation springs up: the responsibility for it passes to the oral literature researcher, who "represents" the creators of oral literature as much as Roland Barthes "represents" Balzac or Jean 
Starobinski Rousseau. But cultural freedom means that UNESCO's communities want to represent themselves, culturally as well as politically, not delegate their representation to persons coming from a former colonial power. Calling for the creation of a manual on preserving oral traditions and expressions, the Intangible Cultural Heritage section of UNESCO stresses

the importance of community involvement in the process of inventorying (including the respect and use of local categorizations for oral traditions and expressions, and the right of communities to decide whether a certain element of their ICH should be included into an inventory or not and thereby respecting taboos and secret elements that may exist) ${ }^{1}$.

How shall communities decide what use to make of their oral literature and their knowledge? How can the foreign expert help?

The question, "Who is 'the other'?" which animated anthropology for so long, is inseparable from the identity question "Who am I?" which has become so politicized in recent years. Researchers in oral literature, foreign though they might be to the communities they were studying, always had a concern for marginalized voices: Eugène Rolland, on hundred fifty years ago, was interviewing street vendors in Paris, and Lars Dahle was interviewing Merina elders in Madagascar. The same concern has animated that school of thought in India called the "subaltern movement", which dedicates itself to re-validating the cultures of marginalized and oppressed people. Being products of elite universities, the subaltern critics are so oriented to Literature, with a capital L, that usually they are deaf to the prodigious results of oral literature research in representing and analyzing the texts of the oppressed, and thereby advocating for them. "What can the intellectual do", asks Gayatri Chakravorty Spivak, "toward the texts of the oppressed? Represent them and analyze them, disclosing one's own positionality for other communities in power" (Spivak, 1990: 56). True, but not a mere hope for the future. The response to Spivak's despair has already come from the study of oral literature. Research into life histories of Marathi women, for example, has shown how much they have to say for themselves. They are concerned about socialization and the development of self, the crucial relationship between mothers and daughters, married life, and the world outside (Apte, 1988: 63-74). The researcher, a male, presents himself as both involved and detached: "Involved because I come from this culture and lived in it for twenty-five years, and detached because I have been away from it for quite a while and have been studying it from a distance" (Apte, 1988: 61). He allows the women to speak for themselves, but his work has not reached the subaltern intellectuals.

"On the other side of the international division of labor from socialized capital", asks Spivak, "inside and outside the circuit of the epistemic violence of imperialist law and education supplementing an earlier economic text, can the subaltern speak?" (1995: 25). How can a sympathetic feminist critic like Spivak keep her gaze so firmly averted from oral literature studies? How can she assume that the voices of marginalized women are not heard, or imagine that the subaltern (or any member of an oppressed group in a poor country) has no voice? Only by disregarding the continual performance of legends, riddles, proverbs and folktales in local communities. The foreign expert in those communities, even a male recording women, hears oppressed people speaking incessantly. Everybody in the island of Ngazidja (Grande Comore) knows why the author Salim Hatubou titled his collection of tales (1994) Contes de ma grand'mère: the 
tales are women's writing exactly in Hélène Cixous's sense (1975). For an audience of Comoran women, that's an accomplished fact.

Constant reminders seem needed: In every society, several modes of literary production exist side by side. Is oral literature quite distinct from written literature, or can both be seen as "verbal art" (Bascom, 1955; Bauman, 1977)? In medieval Europe and modern Africa, written literature continually draws from oral literature. Literary history, as practiced in universities, has long separated the two, and today a scholar can make orality the defining element: "la littérature orale est une littérature à part entière dont la spécificité relève de l'oralité" (Baumgardt, 2008: 385). But they have much in common. Whilst vernacular folklore gets less market attention than literature, a journal like Cahiers de littérature orale shows that telling stories, playing riddles, or singing folksongs are all forms of artistic production, as much as writing novels or producing plays. Both written and oral literature are constituted by structures of production, such as genre and tradition. They are also constituted by performance and publication, the processes an economist calls distribution. Literary production is subject to the influence of artists on one another and the effect of market forces, the process an economist calls exchange. And there is reception by an audience - consumption. These structures of production, distribution, exchange, and consumption show how close oral and written literary systems are to other systems of production in their society. Classics like Le Rouge et le noir, Contes nouveaux ou les fées à la mode, or "La jeune parque" are only beginning to be sufficiently historicized to be read as results of production and exchange, whereas it's quite normal, in the study of oral literature, to replace a creation in its social context (Blackburn and Ramanujan, 1986; Glassie, 1982: 95-156; Bornand, 2005). Would it not help university students to understand the history and principles of literary production and exchange, if only in the history of literature? The economics of serial publication would explain, for instance, the magnitude of $L a$ Comédie humaine and the length of Les Misérables, which make students so impatient.

In most places in the world, the foreign expert confronts a reality that is polyglot and multicultural (Haring, 2004). Literature and oral literature exploit the polyglot speech practices of society. If it was the Russian philosopher-critic M. M. Bakhtin who formulated this insight theoretically, it is oral literature research that has given Bakhtin's insight a startling immediacy. The borders created by history and society, says Bakhtin, and the borders between languages too, act as mobilizers, not impediments. So living in Mauritius, I could see the Indian Ocean throughout history as a highway, not a barrier. The juxtaposing of African, Malagasy, Indian, and European traditions in the islands mobilized creativity. What Bakhtin calls "authentic doublevoiced prose discourse" presciently describes the linguistic habits of Mauritian creoles or Comorans (Blanchy, 1988). He could be thinking of them, or of the Santal of West Bengal in India, when he writes, "The speech of such narrators is always another's speech... and in another's language..." (1981: 313; Carrin, 2001). Studying folk speech in the European Middle Ages and nineteenth-century Russia, he devised the concept of "heteroglossia", the sounding of diverse voices, which oral literature researchers meet every day.

Yet often, the voice of the storyteller, so authoritative in its first setting, is almost entirely absorbed into the voice of an editor, who has assumed the duties of representation. In India as in many other places, the story of oral literature is the story of reframing and recontextualization. A typical reframer there was a clerk, in the 
1920s, who was charged with transliterating certain north Indian tales from Devanâgri to the roman alphabet; he "upgraded the language, primarily by reordering sentences... and changing verb forms" (Wadley, 1986: 198 n. 4). So arises the problem for literary theory: how shall the relation between artistic representation and political representation be conceived? Who will act, speak, or translate on behalf of the oppressed? How shall the oral literature researcher carry out the duties of representation? Years of residing among Tanala people in Madagascar has enabled one to learn their values and translate their myths and tales. Tanala oral literature, he tells us, depicts political tensions and struggles between aristocrats (Zafirambo) and landholders (tompon-tany). The establishment and legitimacy of royal power is the favorite theme, which continually occupies the attention of storytellers and listeners. When storytellers perform these symbolic messages about Tanala society, audiences get the messages semi-consciously through the adventures of characters in narratives (Beaujard, 1991). The foreign expert represents Tanala both artistically and politically. Do his representations elicit any response beyond the community of oral literature researchers?

The Tanala, and every other political community is also an aesthetic community, which is the main source for oral literature research.

"Aesthetic community" merely assumes that, in the area of the "arts and crafts" or "affecting things and events", there is a cultural base, well established in the society and articulated cross-generically via the cultural mechanisms of generic interlock and complementarity, from which the craft mode or affecting mode moves, either in opposition to or in consonance with it. This cultural base may envelop the processes and systems that support and determine the form and shape of the affecting modes native to a culture

- that mystical shadow known as "tradition" that falls over cultural studies - but as well may encompass the possibility of influence by forces and factors external to the culture though not perhaps to the society. Neither the base - the principles, systems, and processes that support a society's cultural-affecting modes - nor the regulating community of participants to which it belongs is static. They are always in process, always evaluating, accepting, or discarding modal elements (Davis, 1976: 177).

UNESCO's conception needs this warning that the aesthetic and the political dimensions of community are inseparable.

Female researchers in oral literature, a bit less foreign, are often able to discover women's ambiguous uses of language. While ambiguity is a universal specialty of oppressed groups, women are especially skilled at them. Feminist researchers of oral literature in the United States have developed a typology of the ways in which women there express themselves, both aesthetically and politically, "in code". One is that "[i]n the creations and performances of dominated cultures, one can often find covert expressions of ideas, beliefs, experiences, feelings, and attitudes that the dominant culture - and perhaps even the dominated group - would find disturbing or threatening if expressed in more overt forms." The utopian effect is that "such coded messages may ultimately help to empower a community and hence to effect change..." (Radner and Lanser, 1993: 4). Women's covert expression is a cultural universal. At weddings in Réunion, people momentarily clothe themselves in the identity that is most appropriate to their needs of the moment (Fuma and Poirier, 1992: 57-58), treating the wedding as a rite of passage. "Certain formal family ceremonies," writes 
one careful observer (I translate), in the heart of creole-speaking groups who are otherwise totally monolingual, require the use of the French language. Letters, proposals, invitations to engagement parties or marriages are traditionally drawn up in French. It is also in this language that romances or songs accompanying festive meals are sung, though the words are often so distorted that they become more or less unintelligible (Chaudenson, 1992: 283).

Behind these shifts into French lies an old African and Malagasy habit. Formal speech functions are assigned to specialists. Certain people are trained to be especially skilled at switching. The specialist will know the diction appropriate to the occasion. Appropriateness is what counts; that is the cultural norm. Because narration and narrators are protected by the convention that folktales are fictional, storytellers exert a greater freedom of linguistic choice than ordinary talkers. They have license to switch up and down the scale of language. Any minority, as oral literature researchers know, needs to develop that skill of indirectness, to protect themselves from the consequences of excessive directness (Calame-Griaule, 1963).

To what extent and in what ways will the foreign expert become the community's ally? Skill with language, which is one object of the research, is the community's defense against power. Wherever people inherit a skill in participating in various traditions, and wherever they got it, their skill is enhanced when converging cultures have different degrees of power. The result is that language, expressive culture, and tradition are all variable. In language in Mauritius, for example, nearly all Mauritians are bilingual, speaking kreol and at least one other language (Bhojpuri - itself a creolized language - French, English, Hakka). To learn to be a Mauritian, whether you are Hindu, Muslim, Chinese, or Creole, you learn the skill of that variability. That will enable you to understand and recognize those who belong to the same "nation", and cope with the others. The researcher too confronts a complex of paths and shortcuts. Skill in participation, for example, encourages a variety of codes; if it is practiced by the community, is it not, for the researcher, Malinowski's "participant observation"? As much as Mauritians wonder about their identity, oral literature researchers wonder too. Both groups might well recognize that what gives them their identity is their capacity for remembering, borrowing, and remodeling cultural patterns. That capacity is more reliable than belonging to a certain family lineage, caste, or class. What characterizes oral literature research, in fact, is that variability.

What about new technologies? The information technology industry is developing and improving these continually. In addition to the familiar camera and cassette recorder, the minidisc is recommended to oral literature researchers, by a linguist with much experience.

For many researchers planning to record oral traditions in out-of-the-way places, a minidisc recorder (with a microphone input, of course) (Hi-MD) and a simple external microphone will be the ideal tool. The combination is relatively inexpensive and sturdy; it delivers recordings of high quality. With a cassette recorder, the same quality of recording can be obtained only with an expensive, external high-end microphone.

Recordings on minidisc can be put in sequence (segmented) without loss of data; the segments can be edited (named, joined, moved); jumping from one segment to the next is easy. Naming and numbering the segments is useful for linking segments of recordings with passages of transcriptions, translations and comments. Easy access to text segments and the unproblematic repetition of small parts of recorded texts are 
important when discussing recordings with the speaker(s) or other people. This way, nobody's patience is challenged too much by waiting for finding the right segment to be discussed.

When using the minidisc-recorder for recording oral traditions, or any other data, it is strongly advised not to use the long-play (LP2 or LP4) modes for recordings, which double or quadruple the possible recording time. Because at first they seem cheaper the same amount of text can be recorded using fewer minidiscs - and more practical one has to carry around and take care of fewer minidiscs - the long-play modes look attractive at first glance. Their setback is that they deliver results with a considerable and audible loss of quality.

Although minidisc equipment is quite sturdy, one may want to make copies of the recorded material. For making copies on minidisc one needs a second minidiscrecorder and a cable connecting the two machines. The recordings can be uploaded onto a personal computer by way of the USB drive.

31 Field workers making recordings under more favorable conditions, in which a higher weight of recording equipment and access to electricity are not a problem, should also consider the possibility of recording directly onto their laptop.

The Digital Endangered Languages and Musics Archive Network presents links to sites with information on hard- and software useful for field folklorists, linguists and musicologists: http://www.delaman.org/links. html\#recording.

The Vermont [U.S.A.] Folklife centre's Audio Field Recording Equipment Guide is a useful and regularly updated web-site with information on hard- and software: http:// www.vermontfolklifecenter.org/ archive/archive-fieldguides.html ${ }^{2}$.

34 A place where the oral literature researcher could advantageously play the role of the foreign expert is to offer to collaborate with other disciplines. The "textual communities" could begin to talk to each other (Haring, 2001). Cognitive science is an example. At the back of all oral literature lies the general problem of the psychology of culture. How does the mind, any mind, know what it knows? How does the mind learn about acceptable ways of speaking, calling up appealing literary symbols, or finding devices to amuse an audience? Oral literature researchers have not yet concerned themselves with this problem, perhaps because it is instilled more in the groups or individuals than in the lore. Answers have recently come out of discoveries in cognitive science, especially in what is called cognitive linguistics. This is a new discipline, which explains language by examining the basic mental processes that govern not only language, but all other areas of human intelligence. Cognitive linguistics discovers that language is situated in a specific region of the mind-and-body - that language, indeed is embodied - and that that region is defined by our biological constitution (Lakoff and Johnson, 1999; Fuchs, 2004). Even our most abstract concepts, the cognitive linguist declares, are rooted in physical experience. Research in oral literature already confirms these assertions. The association of anger with heat, for example, is found among speakers of English and nearly all other languages, Santal for example (Carrin, 2003: 7). Members of both these disciplines know that each person has, within him or her, a plurality of forms of speech - language, dialect, codes, varieties, registers - to use in social interaction. Formulas for greeting or taking leave of someone, oaths, curses, and blessings are genres of oral literature. Hence the data provided by oral literature 
studies is necessary to the cognitive linguist, and the cognitive linguist's findings help to explain oral literature.

Where the two disciplines can collaborate is in probing, more deeply than has been done up to now, the plurality of forms of speech. These forms obviously derive from a person's experience; language is imposed on the individual, in the sense that my language existed before I was born. A capacity for certain aspects of language is imprinted on the physical structure of the brain. This was the discovery of the great Roman Jakobson, which cognitive linguists have built on. Topics in language, Jakobson showed, may be connected either through similarity, which is expressed in a condensed fashion in metaphor, or contiguity, which is expressed in metonymy. Jakobson connected certain kinds of brain injury with an inability to understand one or the other of these figures of speech. People with certain brain lesions could not understand metaphor, the expression of similarity between one word and another; those with other lesions could not understand metonymy. In verbal art - the name Jakobson invented for oral literature - metaphor and metonymy interact. Indeed, Jakobson said, they interact in dreaming, magic, or any symbolizing process. Metaphor, metonymy, style, and structure are human universals in all societies. Some poetic genres, he thought, may feature metaphor, others may feature metonymy - a hypothesis that has yet to be tested across different cultures (1971).

36 So one could ask about any individual: "What have been the social forces that have imposed language on this person"? Here oral literature research needs not only cognitive linguistics, but historical analysis too. Social forces, to be discovered through ethnography, complement the brain's equipment. The combination lights up the cultural significance of orality, which anthropological folklorists discovered first. The structures of language, as we find them, are what they are because of possibilities and impossibilities inherent in language structures mediated by the mind. Its flesh and blood, as it were, the meanings it has for those who use it, the texture that it takes and gives in their speech and reflection, are what they are because of the specific experience [of speakers and hearers] (Hymes, 1980: 74-75).

The collaboration of cognitive linguistics, oral literature research, and historical analysis has great promise. Creole societies show what strong effects the movements of people have on language and expressive culture. In Assam, for example, one of the buranjis from the seventeenth century shows that negotiations across political and linguistic borders produced a new language of communication amongst speakers of different languages - a pidginization of the structure and phonology of Assamese language (Gogoi, 1986: 44). Pidginization is invariably oral; it occurs only as a result of interaction among speakers. Some pidgin languages develop into creole languages. Therefore, where there is pidgin language, cultural exchange has already happened. Wherever there are different languages, however, there may not be pidginization; there may be only contestation. The Indian state of Meghalaya recognizes only two languages for school purposes - Khasi and Garo - though others exist less officially; the state of Nagaland recognizes eighteen or more (Sachdeva, 2002: 157). In Nagaland, the growth of non-Naga population, in a historically homogeneous town like Kohima, leads to more linguistic diversity, therefore more folkloric diversity and more cultural exchange. The arena where Assamese, Nagas, Mizos, and Khasis accumulate most symbolic capital is the art of the word. Regional study of verbal art, both oral and 
written, will be the task for scholarship and criticism in northeast India in the coming years.

The task for cognitive linguistics and oral literature might be a comprehensively transformed theory on the model of a huge synthesis like Stephen Jay Gould's Structure of Evolutionary Theory (2002). Oral literature research does not pretend to the comprehensiveness, power, and scope of Darwinian theory, but it will gain power through doing ethnographic studies of related fields like cognitive linguistics. The transforming of folklore theory will become reality when contemporary thinkers in related fields (textual communities) can come to some agreement.

There are precedents for disciplinary cooperation. In the past, folklorists have not overlooked psychology. As Giambattista Vico saw, it's impossible to study expressive culture without some conception of the human mind. Vico foreshadowed the modern cognitive notion that metaphorical thought is normal and natural to human beings. He even foresaw, in his own jargon, the undertaking of cognitive linguists. "There must," Vico writes,

in the nature of human institutions be a mental language common to all nations, which uniformly grasps the essence of things feasible in human social life and expresses it with as many diverse modifications as these same things have diverse aspects.

(1961: 161) (my emphasis)

The cognitive-linguistic restatement of that comes 350 years later: "Our ordinary conceptual system, in terms of which we both think and act, is fundamentally metaphorical in nature" (Lakoff and Johnson, 2003: 3). Psychology and oral literature studies, as communities, have been lost to each other because cognitive science, concentrating on its chosen region of the individual's mind-body, turned away from the communicative interaction of persons. Oral literature studies, like anthropology, chose to overlook the cognitive study of language. Bringing the fields back together will provide a theory of expressive culture and help explain creativity.

Components of the theory can be seen in citations from authorities in the two fields.

The first principle would be that creativity - in folklore, literature, design, composition, or performance - is "accomplished with the ordinary cognitive resources we all share, using conventional conceptual devices and forms of understanding" (Lakoff et al., 1999: 340). Then come three propositions which cognitive linguistics addresses to oral literature: "The mind is inherently embodied. Thought is mostly unconscious. Abstract concepts are largely metaphorical" (Lakoff et al., 1999:3). The foreign expert might reply, "That is no news. For years I have been analyzing the metaphorical content of Bwa, or Malagasy, or Sibundoy proverbs" (Leguy, 2005; Haring, 1992: 63-97; McDowell, 1989). "But those are poetic facts," says the cognitive linguist. "I'm looking at metaphors that are mechanisms of everyday thought. They are mental facts." If the two disciplines are investigating two distinct sorts of metaphor, the disciplines yet agree that everybody has basic experiences and everybody has conceptual metaphors. Poetic thought in every society "uses the mechanisms of everyday thought, but it extends them, elaborates them, and combines them in ways that go beyond the ordinary" (Lakoff and Turner, 1989: 67). Creativity in oral literature therefore is a set of cognitive acts. What the American folklorist calls socially situated communicative interaction the citing of a proverb or the telling of a tale - takes up these elaborated and extended 
metaphors and gives them a life of their own; they gain community acceptance; they keep turning up in different expressions (Briggs, 1990: 199).

The foreign expert, gradually discerning the outlines of this new community, begins to see that what Vico called a mental language, or what the cognitive linguist calls a conceptual system, is a cognitive process. The word or phrase or sentence is "only the linguistic aspect and expression" of that process. Metaphor is fundamental to human beings, who all carry "primary" metaphors with them all the time. Primary metaphors, as formulated by cognitive linguists, are found in many languages and many proverbs. I draw examples from Madagascar, where primary metaphors, in the cognitive linguist's language, include Important Is Big ("The chameleon's eyes: they stick out a lot, but they "re little"), Difficulties Are Burdens ("Misfortune is like a cloud, when it's heavy enough, it falls"), States Are Locations ("Like the rocks at Ambohimanga, the part in the ground doesn't rot, the part in daylight doesn't crumble"), and Actions Are SelfPropelled Motions ("Human beings go here and there like eels in water"). Creativity in folk or literary poetry is possible because people share conceptual metaphors (Lakoff et al., 1989:55-56). In a metaphorical proverb, there is a "source domain," like the weaving of a mat, and there is a "target domain," like human nature: "Those under heaven are one big mat," says a Malagasy proverb (Houlder, 1957: 1). When Macbeth, in Shakespeare's tragedy, says, "My way of life Is fallen into the sere, the yellow leaf" (act 5, scene 2), the source domain "plants" is mapped on to the target domain "human being," under a basic conceptual metaphor that People Are Plants. Metaphor is "a mapping of a source conceptual schema (such as our conceptual metaphor for journey), onto a target conceptual schema (such as our conceptual schema for life)" (Turner, 1987: 52). The hypothesis is universal; it will be for the oral literature researcher to test it across cultures.

For the cognitive linguist, creativity means connecting source domains and target domains. "The recognition of (real or perceived) shared features between any two domains can create an infinitely large number of novel metaphors" (Kövecses, 2005: 266). Western literary criticism since Aristotle has seen that potential. In eighteenth-century England, writing of poets a century earlier, Samuel Johnson saw this recognition as creative, but he thought the metaphysical poets carried it too far. "Wit," Johnson wrote in his life of the poet Cowley,

[...] abstracted from its effects upon the hearer, may be more rigorously and philosophically considered as a kind of discordia concors; a combination of dissimilar images, or discovery of occult resemblances in things apparently unlike [...] The most heterogeneous ideas are yoked by violence together [...]

(Smith and Parks, 1951: 461)

Today the cognitive linguist defends it: "To see similarity where there is no objective similarity and to see similarity where there is no culturally imposed perceived similarity are true acts of creation" (Kövecses, 2005: 67).

In that case, says the oral literature scholar, riddles are supremely creative: "The greater the initial opposition between the two sets, the more effective the riddle metaphor" (Maranda, 1971: 138). Together, oral literature and cognitive linguistics can define the relation of the conceptual and conscious levels and identify where creation abides. The transformed theory will define the relation between that "basic conceptual metaphor," People Are Plants, and the invention of literary metaphor. 
ativity in oral and written literature starts from these conventional conceptual metaphors, supplied to artists by their culture and accepted by a community. The primary conceptual metaphors people carry with them, which underlie the models supplied to artists by their culture, make possible the generation of new metaphors, not always culturally entrenched, not always conventional (Hart, 1995). One cognitive linguist, who has tried theorizing literature, says that basic metaphors acquire acceptability when members of a community agree, so to speak, to apply "higher-order principles of metaphoric understanding to a certain basic source domain in order to understand a certain target domain" (Turner, 1987:215). Here he is stating the technical underpinning for a distinction made for folklore by Bogatyrëv and Jakobson, relying on the linguist Saussure:

To the extent that... individual innovations in language (or in folklore) correspond to the demands of the community and anticipate the rule-governed evolution of langue (or folklore), they are socialized and form the facts of langue (or elements in the work of folklore).

(Bogatyrëv and Jakobson, $1982<1929>$ : 38) (from the work of folklorist Henry Glassie), the joint theory will begin from physical experiences, which will be the generative basis for primary metaphors like Affection Is Warmth, or Time Is Motion. A human being's abstract ideas will be based on bodily experiences (Lakoff et al., 1999). Then language comes in upon the person. In Lacanian psychology, the means whereby the subject enters language is the "Symbolic", which makes all thinking possible. At this stage (says Glassie), the person is "presented with a stream of images"; on Lacan's logic, that stream will make all artistic creation possible. Then, as the second step, "the incipient maker, the bricoleur, isolates a small number of inherently useless, perfect geometric forms" (Glassie, 1973: 331). As these geometric forms are abstracted from bodily experiences, they are analogous to, perhaps even the same as, the primary metaphors discovered, or postulated, by cognitive linguists. In anthropology this set of forms goes back to Franz Boas, who wrote in 1927,

It is conceivable that elementary esthetic forms like symmetry and rhythm, are not entirely dependent upon technical activities; but these are common to all art styles; they are not specifically characteristic of any particular region.

(Boas, $1955<1927>$ : 11)

51 Symmetry and rhythm are common to all art styles and genres, certainly to verbal art. The universality is expressed in Jakobson's famous formulation: "The poetic function projects the principle of equivalence from the axis of selection into the axis of combination" (Jakobson, 1960: 358). 

old problem, which however cognitive linguists have anticipated: "If metaphors are based on embodiment... and we share much of this embodiment, why are our metaphors (across cultures, groups, and individuals) not at least roughly the same?" (Kövecses, 2005: 259). The commonplace is that human metaphors (myths, for example) are the same around the world, but in fact metaphors and myths are different from culture to culture. Oral literature studies assume the distinctness of cultures; psychologically, there is a congruence between one generic-level metaphor, presumed or found to be quasi-universal, and several specific-level ones. A generic-level conceptual metaphor, writes one cognitive linguist, "is instantiated in culture-specific ways at a specific level" (Kövecses, 2006: 158). The parallel between this view and the identification of folktale "types" noting their variation from society to society, calls for analysis.

in the third step of development, geometric forms or primary metaphors, now established as not innate, are selected by the bricoleur. "The cognitive processes that human beings use are universal, but their applications are not" (Kövecses, 2005: 293). Those applications comprise the phenomena of expressive culture: verbal art, music, dance, painting, sculpture... They are "subject to somewhat distinctive causation" (Edmonson, 1971: 1). If "most of what gives form to individual styles is a result of selection among pre-existing cultural ideas" (1971:200), the theory needs a new concept: conceptual blending.

This new concept, a recent development in cognitive linguistics, offers itself as "the mental capacity that makes human beings human, the one that separates them, and phylogenetically did separate them, from other species and from earlier anatomically modern human beings" (Turner, 2001:52). Members of a culture, or a textual community, use a few basic, conventionalized conceptual metaphors, which their audience shares with them. The poetic metaphor is an extension of such an ordinary conceptual metaphor, which was already resident in thought. Blending yields a new theory of tropes. Linguistically, "an infinitude of potential metaphorical expressions" is available to the artist; they will be realized through the combination, or blending, of a "small number of basic conceptual metaphors". Poets can "versify them in automatic ways", "deploy them masterfully", or "offer new modes of metaphorical thought", thereby destabilizing them (Lakoff et al., 1989: 51). These are the processes of creativity. At this point (the fourth step, continuing Glassie's line of thought), having isolated or selected the forms or metaphors, the artist develops "rules of composition that allow him to design from the abstract to the concrete...". Though these rules may be unconscious, in fact they sometimes are articulated by artists. Applying these rules, a house builder or weaver works "from a finite number of simple, deep organizations of geometric ideas to a vast (if not infinite) number of complex, usable artifacts". These rules of composition effect creation. The rules are "doubtless behaviorally reinforced in context and affected as Boas thought by rhythms of technical activity, but they are not taught and they are used constantly to create previously nonexistent novelties". This is what Sydney Joseph, a skillful traditional narrator I met in Mauritius, meant when he said his new stories had to "rhyme" with the older ones (Haring, 2007: 174-206). Oral literature research has the last word: "it is likely that [...] this characteristically human intellectual dynamic is the same for language and artifacts [...]" (Glassie, 1973:331). Conceptual blending illuminates this dynamic for oral literature. 
56 expert for something in return. To complete the joint theory, something else is needed beyond conceptual blending and the stream of images. Cognitive linguists George Lakoff and Mark Turner write, "Any discussion of the uniqueness or idiosyncrasy of metaphor must therefore take place on two levels: the conceptual level and the linguistic level" (Lakoff et al., 1989: 50). Yes, replies the expert from oral literature, but I need a third level. It is legitimate for cognitive linguists to rely on the mere linguistic level to facilitate their analysis, but the conception is too partial and too narrow, because it omits reference. What objects, persons, or incidents are shown or referred to in a folktale, for instance? What is its "subject matter"? This was the topic Franz Boas drew attention to, when he stated that a collection of folk narrative mirrors the life of the people who tell the tales. Stories point outside themselves to the world.

language. Ignoring these forces is not a realistic way to comprehend metaphor. One can accept the positing of a few generic conceptual metaphors; one can accept the existence of that "infinitude of potential metaphorical expressions at the linguistic level". Still, people's actual metaphorical expressions, at that very linguistic level, are limited, constrained, and pre-selected, by the objects their culture has offered them and the social functions their language inculcates. Just so, the bricoleur's "useless, perfect geometric forms" are limited in number. In relation to its culture, the metaphors in the arts of the word, including proverbs, riddles, myths, legends, and folktales, constitute a selective meta-language. They are their society's way of communicating about much, though not all, of its culture. Counterparts to the selection process that takes place in oral literature are doubtless imposed on potters and weavers and musicians.

The transformed theory, now with three explanatory levels instead of two, would take in both oral and written literature. The theory, after all, is born in the society of printed jokes and electronic mail. Every society has several modes of literary production, some partly nonverbal, coexisting historically but socially disjoined. Transformed theory would have to declare that the basic elements in folkloric communication are not arbitrary, but are as multiply determined as Milton's synthesis of Greek mythology and the Bible in Paradise Lost. To make sure the theory keeps a grip on what people actually do, it could direct its methods towards what Terry Eagleton once called the Literary Mode of Production (Eagleton, 1978:45-48), which "is constituted by structures of production, distribution, exchange and consumption" (Eagleton, 1978: 47). These structures can be found by observing oral or written production everywhere - in Assam, Andhra Pradesh, Algeria, Alabama, and Argentina, on through the alphabet of UNESCO's Intangible Cultural Heritage to Zimbabwe and New Zealand. The theory would authorize examining both the general system of the mode of production, following Franco Moretti (Moretti, 2005) and the individual case of social communicative interaction. It would analyze cultural behavior structurally so as to develop theories that are valid for concrete cases, and comprise "description, historical explanation, critical evaluation, concern with form and with content" (Hymes, 1975: 346). Thus oral literature would be explained as both process and product. This would be the theoretical answer to UNESCO's concern over the disappearance of oral traditions and expressions.

Cahiers de littérature orale, 63-64 | 2008 
literature research today, in the "post-structuralist" era, benefits from being liberated from old restrictions and definitions. Among human behaviors which the brain makes possible, written and oral literature are now seen to be names which certain people have given to mark off certain kinds of expressive behavior. Our theories of oral and written literature are all only modes of talk; university people have agreed to call each one by the same name. All literary criticism is commentary, exegesis, explanation, or exposition; so too are all oral literature studies. Nothing exists, says the postmodernist, but signifying practices, in which people mix lexicons, quote, shift genres and attitudes, and rearrange the components. The production and consumption of verbal art can only be understood as the response of specific groups of people to a specific set of conditions under which they live. All knowledge of them, anthropologist Clifford Geertz reminds us, is local (1983). Therefore, the object of study is the whole field of practices in production and performance, including transcription, translation, and publication. Oral literature researchers look more and more like creole storytellers: they raid "disciplines that do possess distinct bodies of theory, taking a hypothesis here, a concept there, and rearranging them according to the concept [one] is investigating" (Barrett, 1984: 112). Such intellectual raiding is no more than bricolage; it is the central technique of linguistic and cultural creolization, as it is of oral literature scholarship. Perhaps after long histories of nationally independent scholarly traditions, international networks of communication about vernacular culture are beginning to emerge. Perhaps an Enlightenment vision of the community of scholars is being reborn, and at last the results of oral literature research will have broad impact.

\section{BIBLIOGRAPHY}

ABRAHAMS, Roger D. 1993, Phantoms of Romantic Nationalism in Folkloristics. Journal of American Folklore 106, no. 419 (Winter 1993): 3-37.

ANDERSON, Benedict, 1991, Imagined Communities: Reflections on the Origin and Spread of Nationalism. 1983. London: Verso.

APTE, Mahadev L., 1988, Unsung Heroines: Cultural Models of Gender Roles and Selfhood in Marathi Autobiographies. In Life History as Cultural Construction/performance. Proceedings of the Third American-Hungarian Folklore Conference, Budapest, 16-22 August 1987, edited by Támas Hofer and Péter Niedermüller, 50-81. Budapest: Ethnographic Institute of the Hungarian Academy of Sciences, 1988.

AULEEAR, Dawood, and Lee HARING, 2006, Indian Folktales from Mauritius. Chennai (India) : National Folklore Support Centre.

BAKHTIN, M. M., 1981, The Dialogic Imagination: Four Essays. Edited by Michael Holquist. Translated by Michael Holquist and Caryl Emerson. University of Texas Press Slavic Series, vol. 1. Austin: University of Texas Press.

BARRETT, Stanley, 1984, The Rebirth of Anthropological Theory. Toronto: University of Toronto Press. 
BASCOM, William, 1955, Verbal Art. Journal of American Folklore 68: 245-252.

BAUMAN, Richard, 1977, Verbal Art as Performance. Prospect Heights (IL): Waveland Press.

BAUMgaRdT, Ursula, and Jean DERIVE, gen. eds., 2008, Littératures Orales Africaines : Perspectives

Théoriques et Méthodologiques, Ursula Baumgardt and Jean Derive, gen. eds : 385-395. Paris :

Karthala.

BAUMGARDT, Ursula, 2008, Pour une théorie de la littérature orale. In Littératures orales africaines :

Perspectives théoriques et méthodologiques, edited by Ursula Baumgardt and Jean Derive : 385-395.

Paris : Karthala.

BEAUJARD, Philippe, 1991, Mythe et société à Madagascar (Tanala de l'Ikongo) : le chasseur d'oiseaux et la princesse $\mathrm{du}$ ciel. With a preface by Georges Condominas. Paris : L'Harmattan.

BLACKBURN, Stuart H., and A. K. RAMANUJAN 1986, Another Harmony: New Essays on the Folklore of India. Berkeley and Los Angeles: University of California Press.

BLANCHY, Sophie, 1988, Le style des interactions verbales à Mayotte. In Rôles et enjeux : approches d'anthropologie généralisée, 91-123. Saint-Denis : Service des publications de l'Université de la Réunion.

BoAS, Franz, 1955; Primitive Art. 1927. New York: Dover Publications.

BOGATYRËV, Peter, and Roman JAKOBSON, 1982, Folklore as a Special Form of Creativity. In The Prague School: Selected Writings, 1929-1946, edited by Peter Steiner. 1929, 32-46. Austin : University of Texas Press.

BORNAND, Sandra, 2005, Le discours du griot généalogiste chez les Zarma du Niger. Paris : Karthala. BRIGGS, Charles L., 1990, History, Poetics, and Interpretation in the Tale. In The Lost Gold Mine of Juan Mondragon: A Legend from New Mexico Performed by Melaquias Romero, edited by Charles L. Briggs and J. L. Vigil, 165-240. Tucson: University of Arizona Press.

CALAME-Griaule, Geneviève, 1963, L'art de la parole dans la culture africaine. Présence Africaine, $\mathrm{n}^{\circ} 47$ (2d trimestre) : 73-91.

CARRIN, Marine, 2001, Les paroles détournées : formes de discours et rhétorique chez les Santal. Cahiers de littérature orale, $\mathrm{n}^{\circ}$ 50: 47-73.

CARRIN, Marine, 2003, Twisted Speech as a Santal Theory of Discourse. Indian Folklife 2, no. 3 (January-March): 6-11.

CHAUDENSON, Robert, 1991, Mulâtres, métis, créoles.... In Métissages 2 : linguistique et anthropologie, Saint-Denis, Université de la Réunion : 23-37.

CIXous, Hélène, 1975, Le rire de la Méduse. L'Arc : 39-54.

DAVIS, Gerald L., 1976, Afro-American Coil Basketry in Charleston County, South Carolina: Affective Characteristics of an Artistic Craft in a Social Context. In American Folklife, edited by Don Yoder, 151-184. Austin: University of Texas Press.

EAGLETON, Terry, 1978, Criticism and Ideology: A Study in Marxist Literary Theory. NLB. London: Verso Editions.

EDMonson, Munro, 1971, Lore, an Introduction to the Science of Folklore and Literature. New York: Holt, Rinehart and Winston.

Fuchs, Catherine, gen. ed., 2004, La Linguistique cognitive. Cogniprisme. Paris : Éditions Ophrys, Éditions de la Maison des Sciences de l'Homme. 
FuMA, Sudel, and Jean PoIRIER 1992, Métissages, hétéroculture et identité culturelle : le défi réunionnais. In Métissages 2 : linguistique et anthropologie, compilers Jean-Luc Alber, Claudine Bavoux, and Michel Watin. Publications de l'Unité de Recherche Associée (URA 1041) du CNRS, 49-65. Saint-Denis : Université de la Réunion, Faculté des Lettres et Sciences Humaines. GEERTZ, Clifford, 1983, Local Knowledge: Further Essays in Interpretive Anthropology. New York: Basic Books.

GLASSIE, Henry, 1973, Structure and Function, Folklore and the Artifact. Semiotica 7, no. 4: 313-351.

GLASSIE, Henry, 1982, Passing the Time in Ballymenone: Culture and History of an Ulster Community. Philadelphia: University of Pennsylvania Press.

GogoI, Lila, 1986, The Buranjis, Historical Literature of Assam. New Delhi: Omsons Publications. GouLD, Stephen Jay, 2002, The Structure of Evolutionary Theory. Cambridge: Belknap Press of Harvard University.

GREENWAY, John, 1964, Literature Among the Primitives. Hatboro (PA): Folklore Associates.

HARING, Lee, 1992, Verbal Arts in Madagascar: Performance in Historical Perspective. Publications of the American Folklore Society. Philadelphia: University of Pennsylvania Press.

HARING, Lee, 2001, Textual Communities for Oral Literature. Cahiers de littérature orale, $\mathrm{n}^{\circ} 50$, p. 185-205.

HARING, Lee, 2004, Cultural Creolization. Acta Ethnographica Hungarica 49, no. 1-2: 1-38.

HARING, Lee, 2007, Stars and Keys: Folktales and Creolization in the Indian Ocean. Bloomington: Indiana University Press.

HART, F. Elizabeth, 1995, Cognitive Linguistics: The Experiential Dynamics of Metaphor. Mosaic, no. 28 : Unpaged.

Hatubou, Salim, 1994, Contes de ma grand'mère (contes comoriens). Paris : L'Harmattan.

HoLBEK, Bengt, 1978, The Social Relevance of Folkloristics. Unifol: 21-43.

HOULDER, J. A., 1957, Ohabolana, ou proverbes malgaches. Translated by H. Noyer. Tananarive : Imprimerie Luthérienne.

HYMES, Dell, 1975, Folklore's Nature and the Sun's Myth. Journal of American Folklore 88, no. 350: 346-69.

HYMES, Dell, 1980, Language in Education: Ethnolinguistic Essays. Washington: Center for Applied Linguistics.

JAKOBSON, Roman, 1960, Closing Statement: Linguistics and Poetics. In Style in Language, edited by Thomas A. Sebeok, 350-377. Cambridge: MIT Press.

JAKOBSON, Roman, 1971, Two Aspects of Language and Two Types of Aphasic Disturbances. In Fundamentals of Language, authors Roman Jakobson and Morris Halle, 67-96. The Hague: Mouton. KöVECSES, Zoltán, 2005, Metaphor in Culture: Universality and Variation. Cambridge: Cambridge University Press.

KöVECSES, Zoltán, 2006, Language, Mind, and Culture: A Practical Introduction. Oxford: Oxford University Press.

LAKOFF, George, and Mark Johnson, 1999, Philosophy in the Flesh: The Embodied Mind and Its Challenge to Western Thought. New York: Basic Books. 
LAKOFF, George, and Mark Johnson, 2003, Metaphors we Live By. 1980. Chicago: University of Chicago Press.

LAKOFF, George, and Mark Turner, 1989, More Than Cool Reason: A Field Guide to Poetic Metaphor. Chicago: University of Chicago Press.

LEGUY, Cécile, 2005, À propos de la communicabilité du dire proverbial. Réflexion sur l'aspect métaphorique des proverbes. In Paroles nomades, ed. Ursula Baumgardt and Jean Derive, Paris, Karthala, p. 99-113.

MARANDA, Elli Köngäs 1971, “A Tree Grows”: Transformations of a Riddle Metaphor. In Structural Models in Folklore and Transformational Essays eds. Elli Köngäs Maranda and Pierre Maranda, 116-139. The Hague: Mouton.

MCDOWELL, John Holmes, 1989, Sayings of the Ancestors: The Spiritual Life of the Sibundoy Indians. Lexington (KY): The University Press of Kentucky.

MORETTI, Franco, 2005, Graphs, Maps, Trees: Abstract Models for a Literary History. London : Verso. PoIRIER, Jean, ed. and comp., 1968, Ethnologie générale. Paris : Éditions de la Pléiade ; Gallimard. Pound, Louise, 1921, Poetic Origins and the Ballad. New York: The Macmillan Company.

RADNER, Joan N., and LANSER, Susan S., 1993, Strategies of Coding in Women's Cultures. In Feminist Messages: Coding in Women's Folk Culture, edited by Joan Newlon Radner, 1-29. Urbana: University of Illinois Press.

SACHDEVA, R[ajesh], 2002, Exploring Ground Conditions for Code Production in Multilingual Settings: Comparative Notes on Linguistic Landscaping in Nagaland and Meghalaya States in Northeast India. In Linguistic Landscaping in India, with Particular Reference to the New States, Proceedings of a Seminar, edited by N. H. Itagi and Shailendra Kumar Singh, 153-173. Mysore: Central Institute of Indian Languages and Mahatma Gandhi International Hindi University. SARGENT, Helen Child, and George Lyman KITTREDGE, eds. 1904, English and Scottish Popular Ballads. With an introduction by George Lyman Kittredge. Boston: Houghton Mifflin Company.

SEN, Amartya, 1999, Development as Freedom. New York: Alfred A. Knopf.

SMITH, James Harry and PARKs, Edd Winfield, eds., 1951, The Great Critics, an Anthology of Literary Criticism, ed. New York: W. W. Norton.

SPIVAK, Gayatri Chakravorty, 1990, The Post-Colonial Critic: Interviews, Strategies, Dialogues. Edited by Sarah Harasym. New York: Routledge.

SPIVAK, Gayatri Chakravorty, 1995, Can the Subaltern Speak? In The Post-Colonial Studies Readr, edited by Bill Ashcroft, Gareth Griffiths, and Helen Tiffin, 24-28. London: Routledge.

TURNER, Mark, 1987, Death is the Mother of Beauty: Mind, Metaphor, Criticism. Chicago: University of Chicago Press.

TURNER, Mark, 2001, Cognitive Dimensions of Social Science. New York: Oxford University Press.

VICo, Giambattista, 1961, The New Science. Abridged edition no. 3. Translated by Thomas Goddard Bergin and Max Harold Fisch. Ithaca: Cornell University Press.

WADLEY, Susan S., 1986, The Kathā of Śakat: Two Tellings. In Another Harmony: New Essays on the Folklore of India, edited by Stuart H. Blackburn and A. K. Ramanujan, 195-232. Berkeley: University of California Press. 
WILGUS, D. K., 1959, Anglo-American Folksong Scholarship Since 1898. New Brunswick (NJ): Rutgers University Press.

ZIPES, Jack, 1994, Fairy Tale as Myth, Myth as Fairy Tale. Lexington: The University Press of Kentucky.

\section{NOTES}

1. The UNESCO manual, written by the author, is not yet published.

2. The author is grateful to linguist Dörte Borchers for permission to cite her recommendations.

\section{ABSTRACTS}

Oral literature research can be valuable in UNESCO's effort to preserve intangible cultural heritage, or folklore, by precisely depicting the internal differences within communities and the role(s) of individual performing artists. How much the researcher will or should consciously advocate for the community and its oral traditions and expressions is an open question. New technical aids and allied disciplines offer themselves to be mastered, thus enlarging the field of oral literature research. A promising discipline is cognitive linguistics, which could combine with oral literature to fashion a new theory of creativity, both oral and written.

Les recherches en littérature orale peuvent s'avérer précieuses dans le cadre des efforts de l'UNESCO pour la sauvegarde du patrimoine culturel immatériel (2003) en décrivant précisément les différences internes à l'intérieur même des communautés ainsi que le(s) rôle(s) des artistesperformeurs individuels. La question demeure de savoir à quel point le chercheur doit ou devrait consciemment plaider en faveur d'une communauté, de ses traditions et productions orales. De nouvelles techniques et l'interdisciplinarité peuvent contribuer à élargir le champ de la recherche en littérature orale. La linguistique cognitive, prometteuse en tant que discipline, pourrait se combiner avec la littérature orale pour façonner une nouvelle théorie de la créativité littéraire, que celle-ci soit orale ou écrite.

\section{INDEX}

Mots-clés: linguistique cognitive, patrimoine culturel immatériel, préservation

Keywords: Cognitive Linguistics, Intangible Cultural Heritage, Oral Literature, Preservation Subjects: littérature orale 